\title{
Potential Impingement Factors of Information and Communication Technology Usage at Rural Libraries in Malaysia
}

\author{
Samsul Farid Samsuddin 1
}

Siti Zobidah Omar2,3

\author{
Bahaman Abu Samah ${ }^{4}$
}

Jusang Bolong ${ }^{3}$

${ }^{1}$ Sultan Abdul Samad Library, Universiti Putra Malaysia, 43400 Serdang, Selangor, Malaysia ${ }^{2}$ Institute for Social Science Studies, Universiti Putra Malaysia, Infoport, 43400 Serdang, Selangor, Malaysia

${ }^{3}$ Faculty of Modern Language and Communication, Universiti Putra Malaysia, 43400 Serdang, Selangor, Malaysia

${ }^{4}$ Faculty of Educational Studies, Universiti Putra Malaysia, 43400 Serdang, Selangor, Malaysia

Doi:10.5901/mjss.2016.v7n2p360

\section{Abstract}

Rural libraries in Malaysia are purposively built to increase the level of people's knowledge and thus produce an information society, especially in rural communities. The services and facilities provided are expected to change the lifestyle of the local community. The main objective of this study is to suggest the potential impingement factors for Information and Communication Technology (ICT) usage at rural libraries in Malaysia. This conceptual study is based on document analyses and reviews of previous literature to identify the potential impingement factors for ICT usage in rural libraries. A total of four potential impingement factors are identified and discussed by the authors: demographic, individual, behavioural, and ICT. It is hoped that this study's results can assist concerned parties in constructing strategies for improving and further cultivating ICT usage among rural communities in Malaysia.

Keywords: Rural library, ICT usage, information management, rural development, community development

\section{Introduction}

To address the digital gaps within rural communities, the main driving force for realizing value creation in sustainable economic ecosystems in rural areas is through digital empowerment. According to Bhalchandra et al. (2010), rural communities have always been associated with underserved and insufficient facilities and amenities in terms of information access (to updated knowledge, information, and technologies). In efforts to create a knowledgeable community, a sufficient number of libraries with suitable resources must be provided in the local area. The National Library of Malaysia (NLM) was incorporated in 1971 with a mandate, as defined by Wijasuriya (1985), its function to promote free public libraries and library services system in Malaysia. To date, several programmes have aimed to further reduce the information gap, especially among the rural community. One of the established programs is known as the rural library. Nowadays, most of the rural libraries in Malaysia are equipped with ICT facilities. Efforts to provide ICT facilities at rural libraries aim to utilize them as one of the channels to further reduce the digital gap, especially between rural people and their counterparts in urban areas. Nevertheless, despite the availability of these facilities, ICT usage at rural libraries is still not encouraging (Omar et al., 2014). This leads us to ask - why are locals not using the ICT facilities available at rural libraries? This gap - the availability of ICT facilities at rural libraries vs discouraging ICT usage - has driven the main objective of this study, which is to explore the potential impingement factors for ICT usage at rural libraries in Malaysia. The conducting of this study is important to avoid the development of strategies that are unfit for the rural community's ability and interests. The findings of the present study are expected to provide a number of significant contributions to the existing literature, act as a foundation for related studies, and provide useful input into developing rural library strategies that are in line with the needs and interests of the local community. This conceptual study is based on document analyses and reviews of previous literature to identify the potential impingement factors for ICT usage in rural libraries. This methodology been used by identifying the relevant studies from a large pool of research, it does helps to find out what has already been done for better understanding and to grips with the issues that are relevant with the study. 


\section{Rural Libraries in Malaysia}

To further promote the enhancement of knowledge and information seeking among rural residents, rural libraries, or Perpustakaan Desa, have been introduced by the government to provide library services to the rural population (Omar et al., 2012a). Rural libraries are small facilities located in rural areas that serve to provide several information sources and library services to local communities in the area. Since 2000, the establishment of rural libraries has aimed to promote reading habits among rural population, provide useful reading resources to rural communities, help rural students access reading resources for learning, and provide recreational activities related to rural communities (Zainab, Abrizah \& Nor Badrul, 2004).

In 2014, library development in Malaysia continued to progress rapidly with an additional five (5) new 1Malaysia rural libraries being approved to be built in order to bridge the knowledge and digital divide among rural communities (NLM, 2014). The five new rural libraries are well equipped with reading materials such as books, magazines, and newspapers; and facilities such as computers and free WiFi. The rural libraries are also repositories of information for small entrepreneurs to obtain ideas for doing business, as well as to market their existing products and services through the Internet. As of June 2015, NLM manages a total of 501 rural libraries (Table 1) across the country for a total 557,912 cumulative registered users (NLM, 2015). It is reported an operating budget of 30 million Malaysian Ringgit (10 million USD) annually allocated to strengthen the library infrastructure and facilities to enhance the quality of life of rural areas. The total cumulative library collection in the NLM rural libraries is comprised of 4,092,413 copies of book (Table 2). Indirectly, these reading resources will hopefully bridge the digital divide among the rural population and thus create a knowledge society.

Table 1: No. of NLM rural library in Malaysia

\begin{tabular}{lc} 
State & No. of rural libraries \\
\hline Johor & 37 \\
Kedah & 57 \\
Kelantan & 33 \\
Melaka & 28 \\
Negeri Sembilan & 60 \\
Pahang & 32 \\
Perak & 42 \\
Perlis & 37 \\
Pulau Pinang & 33 \\
Sabah & 48 \\
Sarawak & 36 \\
Selangor & 16 \\
Terengganu & 39 \\
Wilayah Persekutuan Labuan & 3 \\
\hline Total & 501 \\
\hline National Library of Malaysia (2015)
\end{tabular}

Table 2: Rural library parameters

\begin{tabular}{lc} 
Parameters & Years 2014 \\
\hline No. of library & 501 \\
Membership cumulative & 557,912 \\
No. of visitors & $2,268,978$ \\
No. of users & $1,851,025$ \\
No. of borrowing collection & $1,330,607$ \\
No. of ICT usage & 596,734 \\
Collection cumulative & $4,092,413$ \\
No. of organize activity & 35,150 \\
No. of public participant & 616,058 \\
\hline
\end{tabular}

Even though the existence of technology has affected the traditional information retrieval process, rural libraries have taken steps to address these challenges by offering ICT services and facilities to rural communities in line with current 
needs and the latest technological developments. Most rural libraries nowadays are equipped with ICT facilities such as computers and Internet connections to maintain their relevance to local communities. Mansoor and Kamba (2010) mentioned ICT as a key enabler in the empowerment of rural communities in developing countries. Rural communities respond in different ways to ICT. Either they will resist ICT adoption or accept it due to information needs. ICT literacy has been shown to influence personal lifestyle (Mansoor and Kamba, 2010). In research conducted by Tenopir et al. (2009), youth were found to prefer to read e-journals (electronic journals) compared to printed version. It has been concluded that there is a drastically changed in information-seeking and reading habits among youth; the existence of the Internet has given them an option to seek information through other channels rather than use rural libraries in the traditional way (Norshila, 2011). The statements above were in line with Omar et al. (2012b) research which also highlighted that given the importance of ICT in closing the information gap, rural library problems such as ICT deficiencies and inadequacy have to be overcome immediately. Furthermore, the potential impingement factors of ICT usage in the rural library in Malaysia need to be identified.

\section{Potential Impingement Factors of ICT Usage in Rural Libraries in Malaysia}

Demographic factors: Studies generally use common demographic factors such as gender, age, race, educational background, profession, or household income to identify the differences that may be derived across studies. However, in the Malaysian context, the majority of rural communities are Malay races in Peninsular Malaysia, and several ethnic races can be found in Sabah and Sarawak. The race dimension is an important demographic factor when considering the whole nation of Malaysia, but less so if the research is only in the context of rural areas in Peninsular Malaysia. Gordon, Moore, and Gordon's (2003) study on public-access computers and libraries in poor neighbourhoods recognized that income and education differences have significance in determining Internet access and use. In addition, Becker et al. (2010) found that 44 percent of the people using public library computers and Internet access in their study were among lower-income households, of which more than half were young adults using ICT for educational purposes. Job search was another popular reason for using library computers among the lower-income patrons. Significantly, Owen et al. (2003) and DeMaagd et al. (2013) found economic position or income to be one of the important dimensions that should be addressed in the demographic factors of rural areas. Other similar dimensions in their research findings were age and education, which agreed with Gomez and Camacho's (2011) study on users of ICT at public access centres. It can be concluded that demographic factors that should be highlighted for ICT usage studies among rural communities in Malaysia are age (young and adult), educational background/achievement, household income (economic position), and employment status (student/unemployed/employed). Besides demographic factors, individual abilities also play an important role and can influence people's actions.

Individual factors: In many research studies, there is a lack of inclusion of individual factors that can influence ICT usage. Pigg (2005) discussed the guidelines for achieving development in a community, and emphasized that it does not depend entirely on the technology, but also individual itself. Awareness, ownership, and experience have attracted attention in previous studies (Owen et al., 2003). An awareness dimension is also in line with the findings of Tobgay and Wangmo (2008). Based on Owen et al. (2003), individuals who have their own equipment or Internet access may have different ICT usage and time-spent patterns than those who do not. Moreover, those who have more experience in using ICT tend to spend more time and fully utilize IT to their advantage in a meaningful manner, such as for education and job purposes. Thus, a higher level of familiarity will reflect a higher level of usage of ICT. Another dimension commonly applied as an individual factor and used in this present study is skills. Digital divides are related to the different skill levels of ICT users that persist although basic access has been provided (Owen et al., 2003; Tobgay \& Wangmo, 2008; van Deursen \& van Dijk, 2009; MCMC, 2014b). In agreement with this statement, Balakrishnan (2002) and Grimes (2000) highlighted how knowledge, skills, and employment opportunities can be enhanced due to ICT services such as the Internet in the rural community context, while at the same time increasing revenues and their business networks.

Internet services strengthen socio-economic development among rural residents. Cecchini and Raina (2002) proved that the Internet promotes gender equality, and improves skills and expertise to provide employment opportunities. The Internet also enables rural farmers to be aware of market prices and profits, and establishes a systematic administrative system. Through employment offers and the development of job skills, poverty problems among rural communities can be indirectly solved (Rao, 2004; Abdul Razaq et al., 2009). Awareness, ownership, experience, and skills are new dimensions or individual factors that measure individual ability in using ICT in rural areas. These abilities can indirectly influence and affect behaviour, either positively or negatively. How these behavioural factors relate to and significantly impact ICT usage among rural areas is discussed in this paper.

Behaviour factors: Various types of studies have been conducted on technology and ICT usage. Each study has 
developed its own theories and models. Theories such as the Theory of Reasoned Actions (TRA), Technology Acceptance Model (TAM), Extended Technology Acceptance Model (ETAM), Theory of Planned Behavior (TPB), and Unified Theory of Acceptance and Use of Technology (UTAUT) are applied (as guidelines) to analyse the ICT usage within rural library services in this study.

TRA describes an individual's behavioural intentions, which consist of their attitude and subjective norms surrounding performance towards the behaviour. The individual's feelings about performing the behaviour can be either positive or negative, and the involvement of beliefs regarding the consequences arising from the behaviour are recognized as the attitude towards the behaviour (Fishbein \& Ajzen, 1975).

TAM, which was derived from TRA, looks at ICT acceptance and use. The two variables of perceived usefulness and perceived ease of use play a major role in determining an individual's intention to use ICT or a system. The intentionto-use variable acts as a mediator of actual ICT/system use. TAM suggests that perceived usefulness is directly impacted by perceived ease of use. Furthermore, Wixom and Todd (2005) attempted to extend TAM by introducing several factors from related models (belief factors). They found that TRA and TAM have strong behavioural elements, and stated that when an individual forms an intention to act, they will be free to act without limitation. However, limited time, ability, environmental or organizational limits, and unconscious habits have been found to limit freedom to act (Davis et al., 1989).

However, the TRA model according to Shin et al. (2014) has several limitations, such as a significant risk of confounding between attitudes and subjective norms. This is because attitudes can often be reframed as norms and vice versa, and can limit the freedom to act. However, this limitation has been resolved by the TPB, in which individual behaviour is driven by behavioural intentions (Ajzen, 1991; Eagly \& Chaiken, 1993). As Ajzen, 1991, behavioural intentions consider an individual's attitude towards the behaviour, the influence of the subjective norms surrounding it, and the individual's experience and perception towards the ease with which the behaviour can be performed (perceived behavioural control (PBC)).

Venkatesh et al. (2003) studied user acceptance of information technology towards a unified view. In their study, eight theories and models were reviewed, such as the TRA, TAM, TPB, the TAM and TPB combined model, motivational model, innovation diffusion theory, model of PC utilization, and social cognitive theory. The study found that one of the points of measurement used in the selected models, which is user intention to use information technology, explained between 17 percent and 53 percent of the variance.

To meet the requirements of the study, factors of 'behavioural intention', which are based on ETAM, inspired by Hu et al. (2003), were considered an important factor to be studied because it makes it easier for individuals to understand and see the need to strengthen their Internet use (Fishbein \& Ajzen, 1975; Davis et al., 1989; Ajzen, 1991; Eagly \& Chaiken, 1993; Venkatesh et al., 2003). ETAM consists of six factors, which are perceived usefulness, perceived ease of use, subjective norms, compatibility, ICT self-efficacy and job relevance. ETAM has proven that once the user perceived usefulness and perceives ease of use towards ICT, it will affect the level of ICT usage. This model emphasizes aspects of perceived usefulness as having a high impact on the use of ICT, which indirectly strengthens consumption when an ICT experience is applied (Hu et al., 2003). ICT self-efficacy also emphasizes the important elements of fostering a high level of ICT usage. Before someone attempts to use the available resources at full efficiency they need to gain confidence in their Internet skills (LaRose et al., 2007). Confidence in using public ICT facilities, such as in rural libraries, may encourage continued use in the future (Lenhart, 2009; DeMaagd et al., 2013).

Almost every routine in the workplace uses ICT with no exception, regarding its important; those living in rural areas also need access to ICT in their daily affairs (Samsuddin et al., 2015). Besides students completing their school assignments, rural residents could use ICT for other purposes, such as online banking, financial records management, and agricultural marketing as examples. Subjective norms can also have an impact on the use of ICT in rural communities. Moreover, individuals who use ICT could influence and encourage these potential users to use ICT. Apart from the above factors of ICT usage, the number of ICT centres provided in the area could also be influenced, nearby ICT shops, volume of family members' ICT usage, and support from relevant agencies.

DeMaagd et al. (2013) found that variables such as self-efficacy, attitude, and perceived social norms derived from the TPB explained significantly more variance in the intentions to use ICT in public facilities than demographic variables alone. In addition, these variables enhanced understanding of how to encourage the use of ICT, such as in rural libraries. Based on previous studies, Chau (2001), Shiro (2008), and Dixon and Siragusa (2009) found that there are positive relationships between attitude and ICT usage. Between ICT acceptance and ICT usage, attitude is said to act as one of the dominant related factors. A positive or negative attitude will result either in an increase in use of, or reluctance to use, ICT (Zhang \& Aikman, 2007). In line with these findings, Mahmood et al. (2000) found support for attitude as an important part of ICT usage that can act as an indicator of technology acceptance if it leads to a positive attitude, and also 
strengthens users' belief that ICT will assist and enhance their task performance. Garland and Noyes (2005) stated that to enhance learning and associated activities users should hold a positive attitude towards ICT through increased confidence levels.

According to Meso and Muse's (2008) study, several factors contribute to a high level of use of ICT; these are perceived ease of use, perceived usefulness, ease of access to ICT, and reliability of the technology. Again, several literature reviews and extensive research have found that intention to use ICT is influenced by perceived usefulness (Argawal \& Prasad, 1999; Venkatesh et al., 2003). Rogers (2003) and Samah et al. (2011) indicated that once a community perceives ICT as useful, it will intentionally create sustainable usage for ICT among its members as long as the perceived benefits exist and are continuous. Low cost of processes, the ability to reach a wider market, and the ability to gather large amounts of information within a short time are found to be dimensions of perceived usefulness (Hassan et al., 2003; Laudon \& Laudon, 2000). These findings support previous studies related to the perceived ease of use, perceived usefulness, and user acceptance of ICT (Dougherty, 1991; Davis, 1989; Pandian, 2000). Moreover, their lifestyle will change with the belief that their life is easier with the use of ICT.

Based on previous studies, attitude variables can be measured as attitudes toward ICT usage. Attitudes towards ICT usage are defined by Smith, Caputi, and Rawstone (2000) as an individual's general evaluation or feelings towards ICT (specific to computer and Internet activities). In addition, Ajzen and Fishbein (1980) indicated that attitude is a result of the individual's summary evaluation (internally and externally). Examples of dimensions cited by the researcher are good-bad, likeable-dislikeable, harmful-beneficial, and pleasant-unpleasant. According to Ajzen's (1988) definition of attitudes, several related components are cognitive (beliefs, knowledge, and expectations), affective (motivational and emotional), and performance (behaviour or actions). The attitude towards ICT measures a person's capabilities in effective ICT usage.

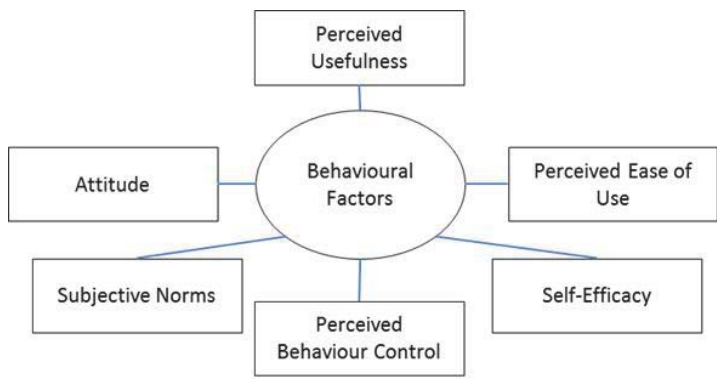

Figure 1: The Behavioural Factors Conceptual Framework

Besides attitude as an important dimension to be included in behavioural factors, or, in other words, intention to use ICT, perceived ease of use, perceived usefulness, subjective norms, PBC, and self-efficacy are other dimensions of behavioural factors. In this paper, behavioural factor components, which can also be referred to as intention-to-use dimensions, have been suggested for future studies on ICT usage in rural communities (Fig. 1). Another factor that can influence the ICT usage of rural libraries is ICT factors. These factors are related to each other, as discussed below.

ICT factors: The existence of libraries is very important for people who do not require ICT access, such as the Internet or computers, from their homes. Access and facilities provided for the public are very crucial in rural areas, especially in terms of technological aspects. MCMC (2014b) reported that in 2011 the majority of household use of the Internet was from urban areas, at 82.2 percent, compared to 17.8 percent for rural. Alternative locations, such as at the workplace, schools, libraries, public Internet access centres, cybercafés, free Wi-Fi at selected premises, and even another person's home (friends/families), are places where people who do not subscribe to the Internet can rely on access away from their home. In addition, for users with an Internet subscription at home, wireless access outnumbered wired access (MCMC, 2014b). Other studies have recommended that to provide details on library Internet-user profiles, information such as their alternative Internet access points and the applications they have accessed (Bertot et al., 2009) is needed. There are various types of ICT access and facilities besides rural libraries, such as at home, work, other public buildings, schools, and restaurants. Thus, availability of facilities and access is a dimension of the ICT factors in the rural community context. 


\section{Conclusion}

In the modern world, where the way people seek and exchange information has rapidly evolved, rural libraries have successfully maintained their role in disseminating information and relevance to patrons. This study has achieved its objectives in exploring the potential impingement factors for ICT usage at rural libraries in Malaysia. A total of four potential impingement factors have been identified and discussed based on previous literature reviews, namely: demographic factors, individual factors, behavioural factors, and ICT factors. These four factors should be included in any future research on rural libraries as they allow researchers to better explore user profiles and diverse information that can improve and encourage patrons to use the services and facilities provided. Collaboration with governments and related parties will also lead to sufficient and successful provisions of ICT and information centres in rural areas. However, this study has limitations on the demographic factors which may not be affected if it is regards the urban area. The findings of this study can help researchers to identify and have a better understanding of user factors, and how users utilize ICT facilities, not only in the rural library context but also that of other rural information centres. The findings of this paper may contribute ideas for instrument constructs for researchers in future studies. Furthermore, it should drive interest in conducting a study to identify the rural youth community's ICT usage at rural libraries in Malaysia. Future studies may include several states that have rural libraries with ICT facilities, as well as rural youth communities.

\section{References}

Abdul Razaq, A., Norhasni, Z. A., Jamaludin, B., \& Pang, S. W. (2009). Computer usage and achievement among adults in rural area Malaysia. Social Science, 5(1), 1-8.

Ajzen, I. (1988). Attitudes, personality, and behavior. Bristol, UK: Open University Press.

Ajzen, I. (1991). The theory of planned behavior. Organization Behavior and Human Decision Processes, 50(2), 179-211.

Ajzen, I., \& Fishbein, M. (1980). Understanding attitudes and predicting social behavior. Englewood Cliff, NJ: Prentice Hall.

Argawal, R. \& Prasad, J. (1999). Are individual differences germane to the acceptance of new information Technologies? Decision Sciences, 30, 361-391. DOI: 10.1111/j.1540-5915.1999.tb01614.x

Balakrishnan, R. (2002). Harnessing ICT for advancement of rural women: FOA perspectives and strategic actions. Paper presented at United Nations Division for the Advancement of Women (DAW) Expert Group Meeting on "Information and Communication Technologies and Their Impact on and Use as an Instrument for the Advancement and Empowerment of Women". Seoul, Republic of Korea, 11-14 November 2002.

Becker, S., Crandall, M. D., Fisher, K. F., Kinney, B., Landry, C. \& Rocha, A. (2010). Opportunity for all: How the American public benefits from Internet access at US libraries. (IMLS-2010-RES-01). Washington, D.C.: Institute of Museum and Library Services.

Bertot, J. C., McClure, C. R., Wright, C. B., Jensen, E., \& Thomas, S. (2009). Public libraries and the Internet 2009: Survey results and findings. College Park, MD: Center for Library \& Information Innovation. [online]. Retrieved April 27, 2015, from plinternetsurvey. org/sites/default/.../publications/2009_plinternet.pdf

Bhalchandra, P. U., Khamitkar, S. D., Deshmukh, N. K., Lokhande, S. N., Phulari, S. S., \& Rathod, R. P. (2010). ICT for rural developments: A review of lessons. Paper presented at the Proceedings of the IADIS International Conference ICT, Society and Human Beings 2010, Part of the IADIS Multi Conference on Computer Science and Information Systems 2010, MCCSIS 2010, 138-142.

Cecchini, S., \& Raina, M. (2002). Warana: The case of an Indian rural community adopting ICT. Information Technology in Developing Countries Working Paper. [online]. Retrieved October 31, 2014, from http://www.comminit.com/en/node/147613/308

Chau, P. Y. (2001). Influence of computer attitude and self-efficacy on IT usage behavior. Journal of End User Computing, 13(1), 26-33. DOI: $10.4018 /$ joeuc. 2001010103

Davis, F. D. (1989). Perceived usefulness, perceived ease of use, and user acceptance of information technology. MIS Quarterly, 13(3), $319-340$.

Davis, F.D., Bagozzi, R.P., \& Warshaw, P.R. (1989). Use acceptance of computer technology: A comparison of two theoretical models. Journal of Management Science, 35, 982-1003

DeMaagd, K., Chew, H. E., Huang, G., Khan, M. L., Sreenivasan, A., \& Larose, R. (2013). The use of public computing facilities by library patrons: Demography, motivations, and barriers. Government Information Quarterly. 30(1), 110-118. doi: http://dx.doi.org/ 10.1016/j.giq.2012.07.009

Dixon, K. C. \& Siragusa, L. (2009). Attitudes towards ICT-based interaction: A bachelor of education case study. Curtin University of Technology Perth, Australia. [online]. Retrieved April 27, 2015, from http://www.aare.edu.au/09pap/dix091331.pdf

Dougherty, K. (1991). The community college at the crossroads: The need for structural reform. Harvard Educational Review, 61(3), 311-337. doi: http://dx.doi.org/10.17763/haer.61.3.k764030285230560

Eagly, A. H., \& Chaiken, S. (1993). The psychology of attitudes. Orlando, FL: Harcourt Brace Jovanovich College Publishers.

Fishbein, N., \& I. Ajzen, (1975). Belief, attitude, intention and behavior: An introduction to theory and research. Reading, MA: AddisonWesley.

Garland, K. J., \& Noyes, J. M. (2005). Attitudes and confidence towards computers and books as learning tools: A cross-sectional study 
of student cohorts. British Journal of Educational Technology, 36, 85-91.

Gomez, R. \& Camacho, K. (2011). Users of ICT at public access centers: Age, education, gender and income differences in users of public access to ICT in 25 developing countries. International Journal of Information and Communication Technologies for Human Development, 3(1), 1-20.

Gordon, M., Moore, E., \& Gordon, A. (2003). Public access computers, libraries, and the poor: Do neighborhood factors make a difference? Bill and Melinda Gates Foundation. [online]. Retrieved June 2, 2015, from http://www.gatesfoundation.org/learning/ Documents/NeighborhoodsFinal.pdf

Grimes, S. (2000). Rural areas in the information society: Diminishing distance or increasing learning capacities? Rural Studies, 16(1), 13-21.

Hassan, M. A., Samah, B. A., Shaffril, H. A. M., \& D'Silva, J. L. (2011). Perceived usefulness of ICT usage among JKKK members in peninsular Malaysia. Asian Social Science, 7(10), 255-266.

Hu, P. J., Clark, T. H. K., \& Ma, W. W. (2003). Examining technology acceptance by school teachers: A longitudinal study. Information and Management, 41(2), 227-241.

LaRose, R., Gregg, J. L., Strover, S., Straubhaar, J. \& Carpenter, S. (2007). Closing the rural broadband gap: Promoting adoption of the Internet in rural America. Telecommunications Policy, 31(6-7), 359-373.

Laudon, K. C. \& Laudon, J. P. (2000). Management information systems: Organisation and technology in the networked enterprise, 6th ed. Englewood Cliffs, NJ: Prentice-Hall.

Lenhart, A. (2009). Adults and social network websites. Pew Internet \& American Life Project. [online]. Retrieved October 10, 2014, from http://www.pewinternet.org/files/old-media/Files/Reports/2009/PIP_Adult_social_networking_data_memo_FINAL.pdf.pdf

Mahmood, M. A., Burn, J. M., Gemoets, L. \& Jacquez, C. (2000). Variables affecting information technology end-user satisfaction: A meta-analysis of the empirical literature. International Journal of Human-Computer Studies, 52(5), 751-771.

Malaysian Communication and Multimedia Commission (MCMC) (2014a). Communications \& Multimedia Pocket Book Statistics, Q3. [online]. Retrieved October 25, 2014, from http://www.skmm.gov.my/facts__figures/stats/index.asp

Malaysian Communication and Multimedia Commission (MCMC) (2014b). Internet Users Survey 2012. [online]. Retrieved October 25, 2014, from http://www.skmm.gov.my/facts_figures/stats/index.asp

Mansoor, Y. \& Kamba, M. A. (2010). Information acceptance and ICT resistance: Promoting the role of information in rural community development. Library Philosophy and Practice (e-journal). Paper 409. [online]. Retrieved February 18, 2015, from http://digitalcommons.unl.edu/libphilprac/409

Meso, P. and Musa, P. F. (2008). Extending the ICT technological culturation model: The role of accessibility and perceived socioeconomic prospects on ICT diffusion. Proceedings of the PrelCIS Workshop by SIG on Global Development, (WSIGGD' 08), Georgia State University, Paris, 1-21.

National Library of Malaysia (NLM). (2014). Perpustakaan Negara Malaysia. [online]. Retrieved February 19, 2015, from http://www.pnm. gov.my/pnmv3/index.php

National Library of Malaysia (NLM). (2015). Bahagian Penyelidikan, Perpustakaan Negara Malaysia. Kuala Lumpur: Perpustakaan Negara Malaysia.

Norshila, S., Masitah, A., \& Wan Nor Haliza, W. M. (2011). Rural youth's perceptions of information sources and rural library services. [online]. Retrieved January 10, 2015, from http://unllib.unl.edu/LPP/shaifuddin-ahmad-mokhtar.htm

Omar, S. Z., Mohamed Shaffril, H. A., Bolong, J. \& D'Silva, J.L. (2012a). Investigating rural library usage among rural youth in Malaysia: Its corresponding determinants and impacts. Computer and Information Science, 5(2), 98-104. Retrieved from http://dx.doi.org/ 10.5539/cis.v5n2p98 on 26th February 2015.

Omar, S. Z., Mohamed Shaffril, H. A., Bolong, J. \& D'Silva, J.L. (2012b). The impingement factors of the rural library services usage among rural youth in Malaysia. Asian Social Science, 8(7), 60-68. Retrieved from http://dx.doi.org/10.5539/ass.v8n7p60 on 26th February 2015.

Omar, S. Z., Shaffril, H. A. M., D'Silva, J. L., Bolong, J. \& Hamzah, A. (2014). Mapping the patterns and problems in using rural library services among rural youth in Malaysia. Information Development, 1-12. DOI: 10.1177/0266666913515506

Owen, D., Green, A. E., McLeod, M., Law, I., Challis, T. \& Wilkinson, D. (2003). The use of and attitudes towards information and communication technologies (ICT) by people from black and minority ethnic groups living in deprived areas. Research Report No 450. The Centre for Research in Ethnic Relations and The Institute for Employment Research, University of Warwick.

Pandian, A. (2000). A study on readership behavior among multi-ethnic, multi-lingual Malaysian students. Paper presented at the 7th International Literacy and Education Research Network (LERN) Conference on Learning, RMIT University: Melbourne, July 5-9.

Pigg, K. E. (2005). Introduction: Community informatics and community development. Community Development: Journal of the Community Development Society, 36(1), 1-8.

Rao, S. S. (2004). Role of ICT in India's rural community information systems. Information, 6(4), 261-269.

Rogers, M. E. (2003). Diffusion of innovations (5th Ed.), New York: The Free Press.

Samah, B. A., Shaffril, H. A. M., Hassan, M. A., \& D'Silva, J. L. (2011). Can technology acceptance model be applied on the rural setting: The case of village development and security committee in Malaysia. Journal of Social Sciences, 7(2), 113-119. http://dx.doi.org /10.3844/jssp.2011.113.119

Samsuddin, S. F., Bolong, J., Omar, S. Z., D'Silva, J. L., Sahharon, H. \& Shaffril, H. A. M. (2015). Examining the impact of demographic factors on the attitude of rural communities in Malaysia towards village WiFi services. Asian Social Science, 11(18), 134-143. http://dx.doi.org/10.5539/ass.v11n18p134 
Shin, D., Lee, J., Yoon, H. \& Choi, M. (2014). How does interactivity contribute to a smart TV user experience? Paper at the Proceedings of the 8th International Conference on Ubiquitous Information Management and Communication. ICUIMC '14, Siem Reap, Cambodia, January 09-11. doi>10.1145/2557977.2557994

Shiro, U. (2008). A case study of DIY ICT. Information, 10(4), 46-60.

Smith, B., Caputi, P., \& Rawstone, L. (2000). Differentiating computer experience and attitude towards computers: An empirical investigation. Computers in Human Behavior, 16, 59-81.

Tenopir, C., King, D. W., Edwards, S. H. \& Wu, L. (2009). Electronic journals and changes in scholarly article seeking and reading patterns. Aslib Proceedings, 61(1), 5-32.

Tobgay, S., \& Wangmo, K. (2008). Can ICT overcome the natural geographic barriers of Bhutan in developing nation? International Education and Development using ICT, 4(4). [online]. Retrieved January 22, 2015, from: http:/lijedict.dec.uwi.edu/view article.php?id=577.

van Deursen, A. J. A. M. \& van Dijk, J. A. G. M. (2009). Improving digital skills for the use of online public information and services. Government Information Quarterly, 26(2), 333-340.

Venkatesh, V., Morris, M.G., Davis, G.B. \& Davis, F.D. (2003). User Acceptance of Information Technology: Toward a Unified View. MIS Quarterly, 27(3), 425-478. [online]. Retrieved October 10, 2014, from http://www.jstor.org/stable/30036540.

Wijasuriya, D. E. K. (1985). Malaysia: the development of library services. Information Development, 1, 75-84. http://dx.doi.org/10.1177/ 026666698500100203

Wixom, B. H., \& Todd, P. A. (2005). A theoretical integration of user satisfaction and technology acceptance. Journal of Information Systems Research, 16(1), 85-102.

Zainab, A. N., Abrizah, A., \& Nor Badrul A. (2004). Building online historical resources collaboratively: making the most of a digital library to reinforce ICT skills in Malaysia. Information Development, 20, 200-210. http://dx.doi.org/10.1177/0266666904046830

Zhang, P. \& Aikman, S. (2007). Attitudes in ICT acceptance and use. In J. Jacko (Ed.), Human-Computer Interaction, 1021-1030. Syracuse, NY: Springer. [online]. Retrieved June 10, 2015, from http://link.springer.com/chapter/10.1007/978-3-540-73105-4_112 